\title{
"Matrix structures in management of quality of educational and scientific work of Ukrainian universities"
}

\begin{tabular}{|c|c|}
\hline AUTHORS & $\begin{array}{l}\text { Oleksandr Velychko } \text { http://orcid.org/0000-0003-2700-0329 } \\
\text { R https://publons.com/researcher/1771375/oleksandr-p-velychko/ } \\
\text { Liudmyla Velychko } \mathbb{D} \text { https://orcid.org/0000-0002-8255-8774 } \\
\text { R https://publons.com/researcher/2015009/velichko-lyudmila/ }\end{array}$ \\
\hline ARTICLE INFO & $\begin{array}{l}\text { Oleksandr Velychko and Liudmyla Velychko (2018). Matrix structures in } \\
\text { management of quality of educational and scientific work of Ukrainian } \\
\text { universities. Problems and Perspectives in Management, 16(1), 133-144. } \\
\text { doi:10.21511/ppm.16(1).2018.13 }\end{array}$ \\
\hline DOI & http://dx.doi.org/10.21511/ppm.16(1).2018.13 \\
\hline RELEASED ON & Monday, 19 February 2018 \\
\hline RECEIVED ON & Friday, 05 January 2018 \\
\hline ACCEPTED ON & Friday, 09 February 2018 \\
\hline LICENSE & $\begin{array}{l}(c) E Y \\
\text { This work is licensed under a Creative Commons Attribution } 4.0 \text { International } \\
\text { License }\end{array}$ \\
\hline JOURNAL & "Problems and Perspectives in Management" \\
\hline ISSN PRINT & $1727-7051$ \\
\hline ISSN ONLINE & $1810-5467$ \\
\hline PUBLISHER & LLC "Consulting Publishing Company "Business Perspectives" \\
\hline FOUNDER & LLC "Consulting Publishing Company "Business Perspectives" \\
\hline
\end{tabular}

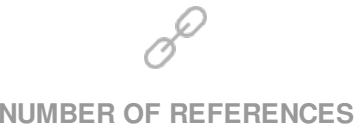

36

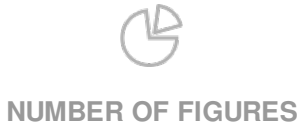

3

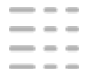

NUMBER OF TABLES

1

(C) The author(s) 2022. This publication is an open access article. 


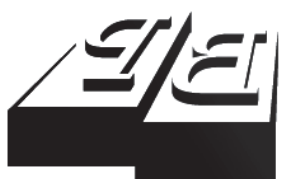

BUSINESS PERSPECTIVES

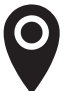

LLC "CPC "Business Perspectives" Hryhorii Skovoroda lane, 10, Sumy, 40022, Ukraine

www.businessperspectives.org

Received on: $5^{\text {th }}$ of January, 2018 Accepted on: $9^{\text {th }}$ of February, 2018

(C) Oleksandr Velychko, Liudmyla Velychko, 2018

Oleksandr Velychko, Doctor of Economics, Associated Professor Head of Management and Law Department, Dnipro State Agrarian and Economic University, Ukraine.

Liudmyla Velychko, Ph.D. in Public Administration, Senior lecturer at the Department of Economics, Entrepreneurship and Management of Enterprises, Dnipro National University named after O. Honchar, Ukraine.

\section{(ㄷ)(i)}

This is an Open Access article, distributed under the terms of the Creative Commons Attribution 4.0 International license, which permits unrestricted re-use, distribution, and reproduction in any medium provided the original work is properly cited.

\begin{abstract}
For the past few years, major progress in providing academic autonomy to Ukrainian universities has been made. However, a large number of universities even now remain the establishments with post-Soviet bureaucratic type of organization of management. As a result, a severe and complicated system of control over current activity has been supported, which requires from scientific and pedagogical workers not only to work effectively, but also to keep the set of rules and procedures. The purpose of the research is to search for possibilities of efficient application by modern universities of flexible matrix structures of management while forming their own internal system of quality control. Threats from bureaucratic management have been generalized for competitiveness of a modern university at the market of educational, scientific and consulting services. The concept and methodology on de-bureaucratization of the system of quality in higher education on the basis of the process approach of the theory of management and rationalistic logistics obtained further development. The mechanism of management of quality at the operational level of the university through integration of the segment-focused approach, system of grading and matrix organization of regular processes has been improved. Ways to apply matrix structure the middle and low levels of managing university have been suggested. Author's recommendations have been provided towards rating evaluation of work of departments and their segment-focused structural organization. The matrix structure of management of quality of carrying out the temporary research project in the university under the conditions of the budget commission has been developed and practically tested.
\end{abstract}

\title{
Keywords higher education, bureaucracy, structures of management, flexibility, efficiency, quality system
}

JEL Classification I28, M12

\section{INTRODUCTION}

Compared to other directions in reforming higher education, the process of post-Soviet transformation of internal university management has unreasonably received insufficiently enough attention to the research of scientists and regulatory politics of bodies of law-making and executive power in Ukraine. Owing to that even now a major part of Ukrainian universities remain establishments with exclusively bureaucratic type of management, which was inherited from the Soviet period.

To a certain extent, such an approach to management of educational and scientific activity in universities can be justified owing to the advantages which this model provides. Among them, according to the theory of "rational bureaucracy" by Veber, clear separation of labor and as a result, appearance of high-qualified specialists; hierarchy of management levels, in which the lower level is controlled by the upper ones; presence of interrelated system of formal rules and standards; formal impersonality with which official people perform their duties; 
hiring people considering technical qualification requirements (diplomas, certificates, licenses and other) and so on (Kaz, 2017; Udy Jr, 1959). Most state and business organizations apply the principles of "rational bureaucracy", which to a certain extent provide them with efficient management and achievement of goals.

Most organizations with bureaucratic management sooner or later gradually dive in the set of complex and sometimes unresolved conflicts which they try to solve without changing the structure.

In such a situation, it is important that an organization should realize the level of bureaucracy of the whole system and the structure of management and gradually start to make them more flexible. Nonetheless, it is possible to form internal teams of consultants, which will not manage the projects but will help managers with professional advice.

At the contemporary and prospective stage of forming management in the higher education in Ukraine, the matrix structures retain great importance; those systems make possible to weaken bureaucratization and flexibly react to changes in the conjuncture at the market. Such structures despite certain advantages compared to bureaucratic have not been widely spread in Ukrainian universities yet. However, in the world, they are widely spread in educational, scientific and innovative spheres in activity of universities, which function within academic autonomy conditions.

\section{LITERATURE REVIEW}

Adizes (2004) and Illés et al. (2015) consider that gradually internal tension starts to deter the organization more and more from the demand of the market, quality and efficiency. The organization is completely concentrated on itself and its internal problems. It tries to keep within all formal procedures, instructions and orders hoping that it will help to solve the issues. At the same time, within the organization, there is not flexible structure, which more and more complicates the speed and adequacy of managerial actions. At that, the complex and cumbrous system of control over current activity remains, which makes workers abide by the rules and procedures but not work efficiently.

Correspondingly, there is no motivation to increase the efficiency and progressive changes. Focus on customer's demands remains low (Khmarskyi \& Pavlov, 2016; Vasylieva, 2013). Within this context, Grynko and Gviniashvili (2017) consider that it is essential to encourage new ideas and decrease the level of the constant control. Under those conditions, the matrix structure of management can be implemented (Habib, 2015; Krzysztof Goś, 2015; Schnetler et al., 2015).

In such a way, Brooks and Kakabadse (2014), as well as Rusinko (2010), described the matrix ap- proach to organization of management in business schools of the USA. These authors paid special attention to disadvantages of matrices for students and administrators. Within this context, Hradilova (2015) studied the process of formation and development of the matrix structure at different levels of management in the Language Center of Preparing Teachers for Masaryk University (France). The possibility of using the matrix approach under conditions of autonomy of higher education has been grounded by Jones et al. (2010) on the example of studying organization of management in universities of Australia.

The matrix structure is also spread in the management of innovative activity of universities. So Browning (2016), as well as Maxwell and Smyth (2010), point out that the matrix is a very useful instrument for managing scientific activity. Such an approach makes possible to concentrate on key features of researches and interrelations between them. Ying et al. (2016) describe the experience of the Harbin Institute of Technological (China) regarding management of scientific and research groups based on the matrix structure. This practice has been identified as useful innovation of the institute. The matrix approach to internationalization of researches in the context of multi-layer management by research universities of Canada has been applied by Jones and Oleksiyenko (2011). 
That is why nowadays it is necessary to carry out examination of advantages of managerial matrix systems under conditions of globalization and modernization of higher education. Possibilities of applying such structures in the business activity of universities with post-Soviet traditions have been insufficiently studied. Mainly those are state universities which function at the market of modern educational services and have achieved considerable progress in receiving academic autonomy for universities according to the existing national regulations.

Hence, Lisyutkin and Froumin (2015) grounded certain influence of increasing the level of bureaucracy in management on the process of degradation in many state universities of the Russian Federation. Based on deep interviews with representatives of universities, the researches revealed the worsening of the condition of productivity in scientific and pedagogical activity (Goncharuk, 2015; Goncharuk, 2016; Tvaronavičienė et al., 2017). At that, the matrix approach to the organization of work has its own niches not only in private, but also in the state sector. It also involves state universities. Johnson McPhail (2016), and Pakarinen and Virtanen (2017) paid great attention to those issues.

Not numerous research of this problem was performed by Ukrainian scientists. In such a way Sharata (2015) considers that universities of Ukraine with divisional and matrix types of management organization possessing better prospect for development. Their main advantage is in the ability to adequately and operatively react to changes both in the internal and external environment. The scientist offered the model of a fourlevel matrix-scale vertical structure of management for university (Ukraine). Within this context, Telizhenko et al. (2016) and Rodionov (2012) pay attention to reasonability of using the matrix approach in management of quality of higher education in Ukraine.

Besides, in most studies by Ukrainian scientists, recommendations include the type of changes in the organizational structure only by its form. The basis for such suggestions is the creation in universities of additional structural subdivisions (centers, divisions, departments, councils of quality con- trol) without special reformation of changes in the existing managerial conditions. Most frequently formation of internal system of providing quality control in education of most Ukrainian universities ends at this point. But as practice shows, only inclusion to the organizational structure of universities of specialized bureaucratic control or central body on quality, problems of increasing competitiveness of educational and scientific services cannot resolve the problem significantly.

In the process of the research, we also considered procedures, possibilities and limitations of the existing system of quality provision for higher education in Ukraine. In particular, according to the existing national regulations, the issues of educational activity and quality control over higher education in general have been considered separately. Moreover, the process of quality control includes three levels: 1) systems of providing quality for higher educational establishments (system of internal provision of quality); 2) system of external provision of quality; 3 ) system of providing quality of the National Agency on Provision of Higher education and independent establishments of estimation and provision of quality for higher education. At that, the system of internal provision of quality at the level of university implies the performance of such measures as definition of principles and procedures of providing quality to higher education; carrying out monitoring and periodical revision of educational programs; annual estimation of students who obtained diplomas of higher education, scientific and pedagogical and pedagogical workers of higher education and regular publication of results of such estimations; provision of increased qualification of pedagogical, scientific and scientific and pedagogical workers; provision of presence of necessary resources for organizing the educational process; provision of availability of informational systems for efficient management over the educational process; provision of public information about educational programs, levels of higher education and qualification; provision of efficient system for preventing and defining academic plagiarism in scientific works and applicants for higher education (Zakon ..., 2014).

That is why in the system of management of quality of higher education in post-Soviet countries, great attention should be paid to changes in type 
of managerial decisions at average and low levels of management in universities. Those levels are more distinctly close to direct operational processes in educational, scientific and consulting activity, as well as quality of fulfilling orders.

\section{MATERIALS AND METHODS}

Materials for the research were chosen from the principles and procedures of quality provision by European Association for Quality Assurance in Higher Education (Standards ..., 2015), provisions of international standards on general quality of education ISO 9001:2015 (ISO ..., 2015), current Ukrainian legislation (Zakon ..., 2014) on quality of higher education, as well as surveying, questioning or benchmarking (Khmarskyi \& Pavlov, 2017) in 27 leading universities of Ukraine, the Russian Federation, Belarus and Kazakhstan and so on.
Methodology of the research was based on the integrated application of traditional methods, as well as the author's methodological approach to the formation of procedures on the quality of higher education at the university level. In the process of the research, monographic and graphic approaches, as well as other specialized methods such as comparison, generalization, surveying, questioning, observation, benchmarking, experiment, and so on were used.

The research was carried out at two stages. At the first stage, the feature of applying matrix systems for organizing management of quality under conditions of constant work of the university were studied. At that, the main attention was focused on the average and low levels of management. At the second stage of the research, the possibilities of applying the matrix structures for organizing the management for temporary projects of universities were studied.

\section{MAIN PRINCIPLES OF MANAGEMENT OF THE QUALITY SYSTEM}

Focus of the university on customer of educational and scientific and consulting services

Leading role in the system of management of quality in the administration of the university

Approach to decision-making on quality management based on facts

Attraction of students, graduates, employers to management of quality in educational services

Process and system approaches to management of educational and scientific and consulting services in the university

Constant enhancement in quality of educational and scientific and consulting services

Relations with organizations-partners and benchmarking of quality management for services of a university in the region and in the country

Social responsibility of university to the society

Figure 1. Main principles of quality management system in a contemporary university 
Table 1. Distinctive features of the author's concept and methodology of internal management of quality of higher education on the basis of the process approach

Source: Developed by the author.

\begin{tabular}{|c|c|c|}
\hline Criterion for comparison & $\begin{array}{l}\text { System of internal provision of quality of } \\
\text { higher education (existing methodology in } \\
\text { Ukraine) }\end{array}$ & $\begin{array}{l}\text { System of internal management of quality of higher } \\
\text { education on the basis of the process approach (the } \\
\text { author's methodology) }\end{array}$ \\
\hline Main mission & $\begin{array}{l}\text { Implementation of requirements of Law of } \\
\text { Ukraine "On Higher Education" }\end{array}$ & $\begin{array}{l}\text { Formation of new psychology and philosophy in } \\
\text { management of the university }\end{array}$ \\
\hline Object of attention & Quality of higher education & Quality in general \\
\hline Focus on the process & Provision of quality & Management of quality through the process approach \\
\hline $\begin{array}{l}\text { Approach from the position } \\
\text { of }\end{array}$ & Standardization & Competitive development at the market \\
\hline $\begin{array}{l}\text { Achieving the level of } \\
\text { quality }\end{array}$ & $\begin{array}{l}\text { Requirements for standards, sufficient for } \\
\text { certification of educational quality (minimal) }\end{array}$ & Constant improvement of quality (infinite) \\
\hline $\begin{array}{l}\text { Application of the } \\
\text { international experience of }\end{array}$ & The EU & The EU, the USA, Japan \\
\hline Innovativeness & $\begin{array}{l}\text { Main focus on the established procedures } \\
\text { which are used in the EU }\end{array}$ & $\begin{array}{l}\text { Creative approach: integration of the existing world } \\
\text { practices, managerial experience in Ukraine, as well } \\
\text { as national scientific and practical developments }\end{array}$ \\
\hline Methods & $\begin{array}{l}\text { Concentration of the known specialized } \\
\text { methods and approaches to provision of } \\
\text { quality of higher education }\end{array}$ & $\begin{array}{l}\text { Combination of methods and approaches to } \\
\text { management of quality directly in the sphere of } \\
\text { higher education with successful business practices }\end{array}$ \\
\hline Focus of attention & $\begin{array}{l}\text { Top management and specialized divisions } \\
\text { on quality of higher education }\end{array}$ & All level s of management and contact personnel \\
\hline $\begin{array}{l}\text { Prevalent type of structure } \\
\text { in management of the } \\
\text { university }\end{array}$ & $\begin{array}{l}\text { Bureaucratic (line-staff, line-functional, } \\
\text { divisional an so on) }\end{array}$ & Adaptive (matrix, project, program-target and so on) \\
\hline $\begin{array}{l}\text { Maintenance of a high level } \\
\text { of quality through }\end{array}$ & Control & Control and self-regulation \\
\hline
\end{tabular}

The process of the research was focused on the system of basic principles of management of quality, which must be kept by any contemporary university (Figure 1).

The author's concept and methodology of forming the system of internal quality provision of higher education through management of quality on the basis of the process approach and rationalistic logistics were developed (Velychko \& Velychko, 2017). Particularly, the system of internal quality provision of higher education on the basis of the process approach possesses a set of differences from the analogous system which is approved in the current Ukrainian legislation (Table 1).

Besides, unlike the previous researches (Cermak \& Hutyra, 2010), management of quality there is viewed as a coherent implementation of the following processes: study of requirements, formation of the strategy, development of programs, organization of cooperation, stimulation of quality and certification of quality. But the author's concept of rationalistic logistics implies the processing of scientific principles, formal models and method of grounding decisions (Velychko, 2015) and rationalistic organization of business processes (Velychko, 2014).
Those developments were used during the formation of the mechanism of organizing interaction at the operational level of managing the university, as well as during the development of the flexible matrix structure for management of the quality of carrying out the contemporary research project.

\section{AIMS}

The purpose of the research is to look for possibilities of efficient application by modern Ukrainian universities of flexible matrix structures of management at formation of own internal systems of quality provision. To achieve the established goal, the following tasks should be solved: determination and systematization of threats from bureaucracy in management of quality under conditions of post-Soviet transformation of higher education; development of the author's methodological approach to formation of procedures on quality of higher education at the university level; development of the mechanism of the university management at the middle and low levels of management of quality on the basis of the segment-focused approach, system of grading and matrix organization; formation of the model of the adaptive matrix 
structure for managing the quality of carrying out the temporary research project by the university and its approbation under practical conditions.

\section{RESULTS AND DISCUSSIONS}

At the first stage of the research, it has been determined that the bureaucratic model of internal university organization of control over quality which is spread in the system of higher education of postSoviet countries possesses significant deep disadvantages (regardless of many advantages provided by the strict hierarchical structure).

However, quite often the process of specialization for workers inevitably leads to the increase in a number of management workers and intensification of its bureaucratism. And bureaucratism implies the domination of the formal approach to business activity. Members of the bureaucratic organization try to carry out their work according to a set of standard routine operations. Under such conditions, workers try to strengthen their position and show their own irreplaceability. For that purpose, they often create for themselves additional types of work, which is pointless from the point of view of achieving goals of the organization. Besides this very approach leads to the increase of role and influence of workers in the organization and sometimes their career growth.

The consumer of services could experience inadequate reaction to the changes of their demands, hence, all problems will be solved based on the existing set rules. If workers of bureaucratic organizations are pointed at inadequacy of their actions, they defend themselves by referring to the existing standards, procedures or instructions. At that, such a worker cannot be punished for from official point of view of his organization, his actions are absolutely correct.

It significantly prevents many Ukrainian universities from performing their mission with a high quality under new conditions of widening academic, staff and financial autonomy. At that, among the administrative personnel in strict hierarchal structures of universities, there are two types of bureaucratic managers. The first one tru- ly believes in absolute powerfulness of rules and possibilities to predict and regulate everything with the help of those rules. At that, it uses norms, instructions and standards and even attempts to achieve purposes and interests of the higher educational establishment or a structural division managed by them. But in this case, the needs of customers and individual interests of each worker are often insufficiently considered or totally ignored. The other type is not interested even in purposes and interests of the organization or its structural subdivision, only own success and welfare matters for him/her and he/she is ready for anything to achieve it. Hence, the effectiveness of activity of higher educational establishments with such a system of quality control very much depends on possibilities and moral features of a certain manager, as well as correspondence of purposes of a university or a structural division with his/her own purposes not vice versa.

Nowadays, under conditions of extremely high competition at the market of educational services, the main purpose of the activity of many higher educational establishments is maximally high training of specialists. The management system should be focused mainly on that. Major qualitative changes in efficiency of work of educational establishments should be made through real application of market democratic foundations of the organization of management. One of the ways to weaken bureaucratic management in modern university and to increase the efficiency of its work can be the application of the matrix structure.

Based on the purpose mentioned above nowadays, it is important to walk away from the existing principle of mandatory complex participation of professors in all possible directions of university's activity: educational, methodological, scientific, pedagogical, consulting and so on. From the positions of philosophy of modern educational requirements, the absence of complex work of a teacher is in fact considered as the insufficient level of qualification and professional growth. It essentially contradicts the idea of efficient potential use of separate workers who could be more capable in one or two types of activity and have an insignificant interest or talent for other teachers. Such an approach often leads to situations when for example, a worker of the department who has a 
scientific degree and achievements in the research work cannot in comprehensive and qualified manner provide the necessary educational material for students. On the other hand, a skilled lecturer and compiler of scientific and methodological literature cannot perform efficient consulting activity for practical business workers. There can be an enormous number of such examples. But it is worth noting that it is the department which is maximally close to direct operational processes in educational, scientific and consulting activity, as well as a quality of carrying out orders.

Therefore, the head of the modern department who provides multi-vector development of a certain direction of professional work should have possibilities to use more efficiently the potential of his/her workers. At the same time, it will provide both psychological and professional satisfaction to workers themselves, enhance the quality of work of the department in all directions of its activity. For that purpose, it is necessary to review some principles and regulations of forming loads on colleagues.

Changes in the structural organization of work in the department are also necessary. Hence, a modern department should include separate sections: educational, scientific and methodological, scientific and research, consulting and so on. Professors of universities should be able to have a chance to work in one and in several sections. Surely, prominent scientists from other universities, scientific or consulting establishments may participate in the work of the sections in the departments. It can significantly increase the level of work efficiency in some directions.

The head of the department as an erudite specialist, first of all should be focused on qualified management for successful work of all sections. It is reasonable to estimate general efficiency of department's work by score rating of all its workers. Such a rating should be defined by customers of educational or other services by anonymous surveying. For that purpose, it is necessary to develop a system of general criteria in directions of activity which would be included in the survey as well as to determine the subjects of surveying. The latter may be such customers of university's services as students, graduates, enterprises, establishments, organizations and so on. The system of estimation should be built on objective and high level of trust.

Such procedure of estimation of work in the department and its head will eradicate or significantly minimize the possibilities of participation of non-professional workers at work. But under those conditions, the formation of staff personnel of sections, the major role in it should be occupied by the head of the department.

For example, in the students' environment criteria for rating estimation of professors at the department could be: freely comprehension of the program material, availability and simplicity of teaching material, paying attention to clarification of difficult moments, ability to cause and maintain interest to the subject, orientation on usage of the material in future professional activity, exactingness to knowledge, polymath, interest in enhancement of students' knowledge, objective evaluation, kind attitude to students and so on.

While using the matrix structure of management, the head of the department must not be a linear manager of his/her structural subdivision unlike the bureaucratic model (Figure 2).

$\mathrm{He} /$ she will carry out only functional influence on co-workers of different sections with contextual issues of their activity. In such a way, he/she should be responsible in the first place for qualitative side of the department's work. In the competence of the head of the department, it is reasonable to include functions toward the team of specialists for efficient performance of the received educational load of the department (so-called profile of orders), as well as to define the content and volume of work of co-workers.

Deputy deans on the corresponding areas of work also carry out functional influence on workers of the department, but on organizational and administrative issues (instructions, organization, control over standards and other requirements, solutions of issues on providing resource possibilities of work, reporting and so on).

Important place in the provision of qualitative competitiveness for rendering educational and other services of the university is occupied by the 


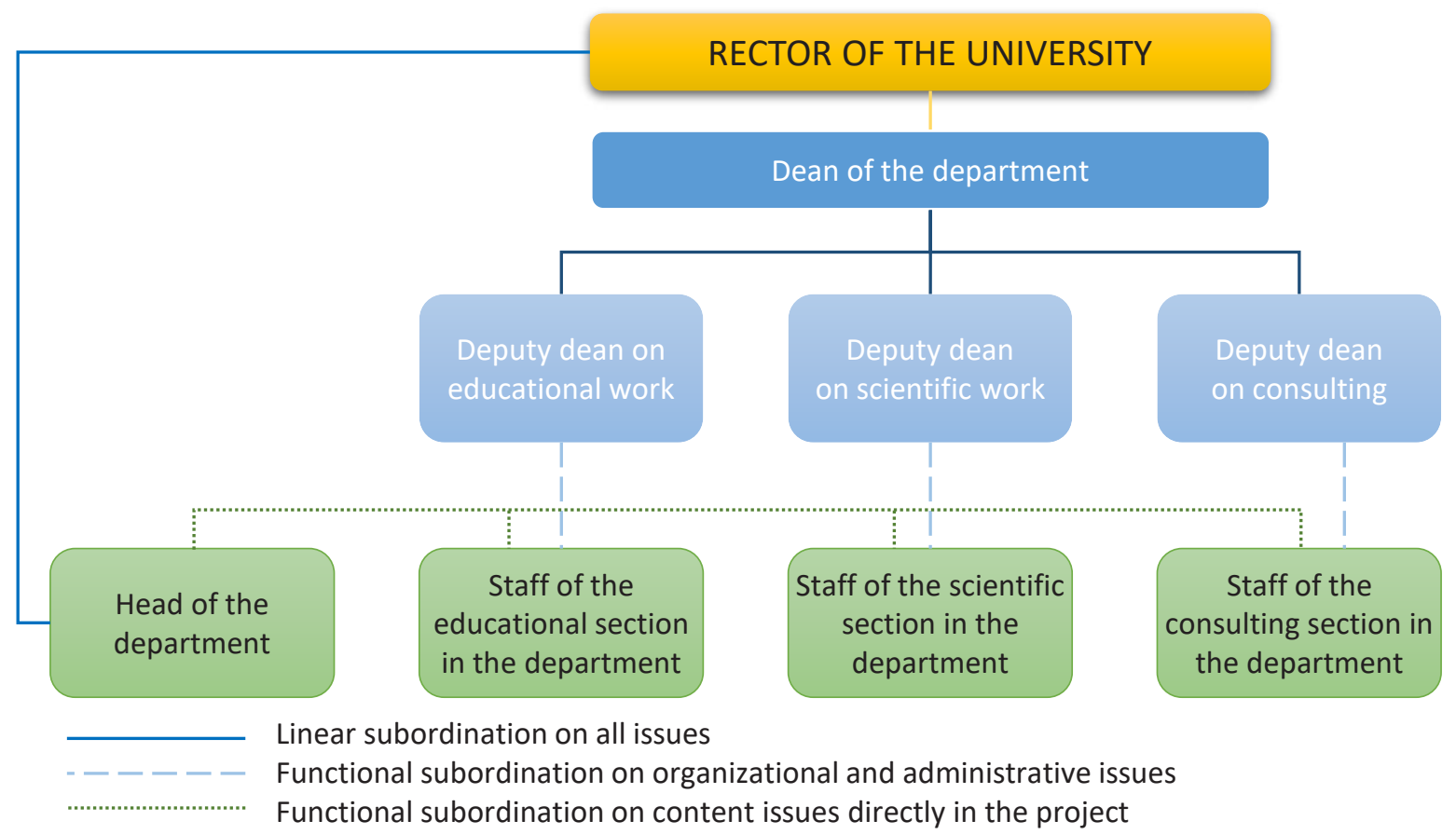

Figure 2. Scheme of the matrix management structure in the internal system of providing quality control of higher education

efficient mechanism of stimulating the work of workers. Principles of so-called "equalization" or subjective evaluation of professors in salaries or bonuses should be eliminated from such an organization. Material motivation of workers is compulsory to be dependent on the quality of results of their work and their duties both in educational, scientific and methodological and scientific directions of activity. Hence, elements of the grading system should be applied (Nepal, 2012).

Thus, unlike the existing approaches (Sharata, 2015; Pakarinen \& Virtanen, 2017; Telizhenko et al., 2016), the mechanism of management of quality at the operational level of the university has been suggested; it is mainly focused on contact personnel and provides support of a high level of quality not through the procedure of the bureaucratic control, but through adaptability, counterweight system and self-regulation.

At the second stage, the results of implementing the author's model of organizing management of temporary scientific project in Dnipro State Agrarian and Economic University (DSAEU, Ukraine) were studied on the basis of the metric structure. Since 2014 , after reassignment of the university, it ob- tained the possibility to participate in competitions of the Ministry of Science and Education of Ukraine on financing certain research projects at the expense of the state budget.

On competitive terms, the university received grant financing on the fundamental theme "Management of the development of agricultural markets, agrarian and ecological logistics in the system of food security". For the implementation of the project, the scientific group was formed which included leading scientists of DSAEU, as well as separate scientists from other universities of Lviv and Odesa (Ukraine). Franchiser of the project is Dnipro State Agrarian and Economic University.

The practice of the project management confirmed the fact that in order to provide the implementation of the set tasks, the most efficient organizational solutions are: constant involvement of prospective scientists in the project, periodic rotation of scientific workers, as well as the application of the developed model of the matrix structure for the management of the project (Figure 3).

In such a structure, the management is carried out by the two-scale system, which forms certain anti- 


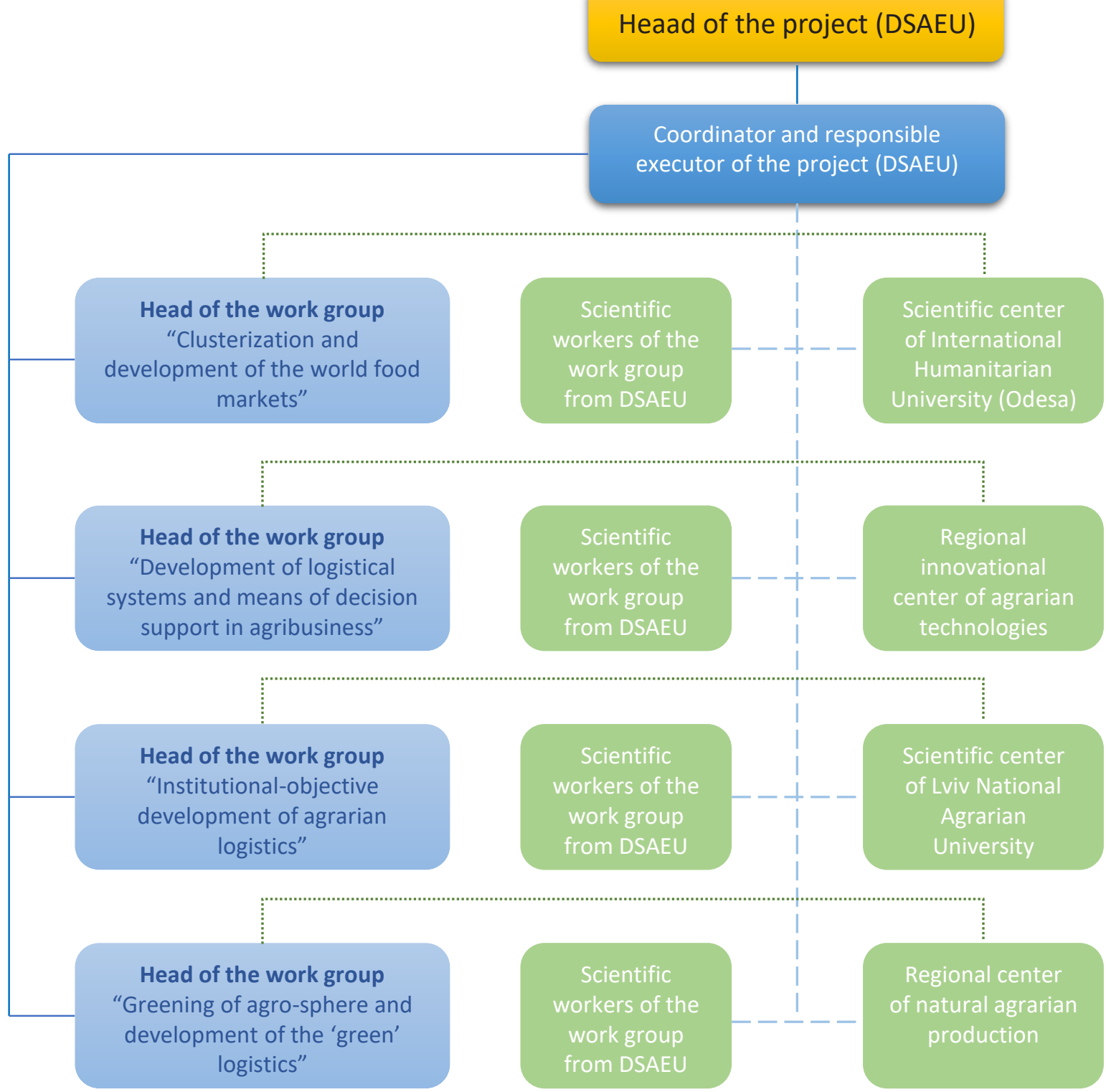

Linear subordination in all issues of the project

Functional subordination in organizational and administrative issues of the project Functional subordination of the content issues of the direction of the project

Figure. 3. The model of the matrix structure of managing the implementation of the scientific project "Management of the development of agricultural markets, agrarian and ecological logistics in the system of food security", 2017-2019

levers. Therefore, every executive has two managers with strictly separated competence: one is responsible for solving organizational and administrative tasks (provision different resources for work, reporting, increase in qualification, stimulation of labor and so on); the other manager supervises the contextual side of the work.
Implementation of the developed model provided a set of advantages in comparison with the administrative and bureaucratic control. Among them are the following: qualitative content management over separate directions of the project, as well as efficient coordination of performing quite different research solutions. 
The interim result of the project was successful completion and partial fulfillment of certain competitive commitments by a set of statistic indices (publications in Scopus and Web of Science, monographs, defense of dissertations, patents, grants, business agreements and so on).

Implementation of the project encouraged the increase in a number of publications and quoting of the researches in most respected international scientific-metric bases. Besides, world ratings of the universities, which were participants of the project, increased. This situation in general intensified the competitive possibilities of Dnipro State Agrarian and Economic University at the market of the research services both in agrarian and in economical spheres.

Hence, the efficacy of the developed model of the matrix structure of management of the quality of implementing of the scientific project by the uni- versity was checked experimentally. This model is positively different form the existing analogues (Browning, 2016; Ying et al., 2016; Maxwell \& Smyth, 2010) due to a high focus of the work, as well as a possibility to more efficiently coordinate the interaction of the personnel under the conditions of carrying out versatile research tasks.

Democratic reforms in the environment of higher education include the change in psychology of workers in post-Soviet universities. Hence, such values in management as hierarchy, authority, discipline, centralization and so on must be considered less efficient. They should be replaced by other, considerably more progressive values focused on the intellectual and creative potential of the professor's personality. For instance, self-expression, target on demands, development of the potential, critical thinking, creative approach, efficiency of work, personal responsibility, ability to compromise, decentralization and so on.

\section{CONCLUSION}

Regardless of the extension of the status of the academy and staff autonomy, majority of Ukrainian universities even now remain establishments with bureaucratic type of organization of quality control. It frequently decreases the motivation to efficient work and implementation of progressive changes in dynamic competitive environment. At that, the solution of new problems of higher education must be done through application of new methods and approaches.

The system of internal provision of quality of higher education must be provided through the concept and methodology of management over quality based on the process and logistical approaches. Under those conditions, the focus is drawn from the level of top management to specialized subdivisions in the quality of higher education at all levels of managing the university and contact personnel. Such an approach also encourages the spread of adaptive managerial structures in the university; those structures will provide a high quality level support not through the procedure of the bureaucratic control, but through flexibility high motivation and self-regulation.

Application of the adaptive matrix structure of management in the system of internal provision of quality of universities may have certain advantages over a bureaucratic one. At the middle and low level of management, such a structure provides a high target focus of work, as well as qualitative content management of current educational, educational and methodological, scientific, consulting and other segments of activity of a higher educational establishment. At that, experts do not need to be distracted for solving routine control functions, organizational problems and so on. But among the most important achievements of such a managerial organization is that there is rational distribution of powers and responsibilities and different managers a sort of counterbalance each other. Such counterbalances in the system of management weaken its bureaucracy. At that, there are smaller risks of dubbing control and other functions. There are favorable conditions for implementation of own potential both for experts and administrators.

The results of the research can be used in the system of management of the quality of universities. 


\section{ACKNOWLEDGEMENT}

The work has been funded by the Ministry of Education and Science of Ukraine. The research was carried out within the context of tasks for scientific projects: "Concept of transformation for organizational-economic mechanisms of management and logistics for enterprises in the system of economic safety of Ukraine" ((No. ID:62198 22.08.2016 (64-1)) and "Management in development of agricultural markets, agrarian, ecological logistics in the system of food safety" ((No. ID:64770 26.08.2016 (00009-1)). The projects were recommended by the National Council of The Ministry of Education and Science of Ukraine for financing at the expense of the state budget.

The research was carried out also within the context of the tasks of Ukrainian-American international project "Training and Development of the management personnel of the Ukrainian Universities" which was initiated by the investment company "Rayter Inc." (Dallas, TX USA). The goal of the program is the assistance of the educational reform in Ukraine, by professional development of management employees of Ukrainian Universities.

\section{REFERENCES}

1. Adizes, I. (2004). The Ideal Executive: why you cannot be one and what to do about it: a new paradigm for management $(295$ p.). Santa Barbara, California. The Adizes Institute Publishing. Retrieved from http://adizes.com. $\mathrm{mx} / w p$-content/uploads/The_Ideal_ Executive_Sample_CH.pdf

2. Brooks, M., \& Kakabadse, N. K. (2014). Introducing matrix management within a children's services setting-personal reflections. Management in Education, 28(2), 58-63. Retrieved from http:// citeseerx.ist.psu.edu/viewdoc/down load?doi $=10.1 \cdot 1 \cdot 950.9021 \&$ rep $=$ rep $1 \&$ type $=$ pdf

3. Browning, T. R. (2016). Design structure matrix extensions and innovations: a survey and new opportunities. IEEE Transactions on Engineering Management, 63(1), 27-52. https://doi.org/10.1109/ TEM.2015.2491283

4. Cermak, T., \& Hutyra, M. (2010). Quality management system as the basis of quality assurance at VSB-technical university of Ostrava. Polish Journal of Management Studies, 1, 119-126. Retrieved from http://docplayer.net/38359302Quality-management-system-asthe-basiss-of-quality-assurance-atvsb-technical-university-of-ostravacermak-t-hutyra-m.html

5. Goncharuk, A. G. (2015). Management Education in Research. Journal of Applied Management and Investments, 4(3), 151-155.
Retrieved from http://www.jami.org. ua/Papers/JAMI_4_3_151-155.pdf

6. Goncharuk, A. G. (2016). Evaluating the Efficiency of Higher Education. Journal of Applied Management and Investments, 5(2), 82-91. Retrieved from http://www. jami.org.ua/Papers/JAMI_5_2_8291.pdf

7. Grynko, T., \& Gviniashvili, T. (2017). Organizational and economic mechanism of business entities' innovative development management. Economic AnnalsXXI, 165(5-6), 80-83. https://doi. org/10.21003/ea.V165-17

8. Habib, K. A. (2015). Making the matrix work: how can conflict be managed when introducing the matrix organization structure in growth markets; a case study in the Middle East (Doctoral dissertation). Heriot-Watt University. Retrieved from http://www.ros.hw.ac.uk/ bitstream/handle/10399/3018/ HabibK_0315_ebs.pdf?sequence=1

9. Hradilova, A. (2015). Language centre matrix management structure: Developments in teacher training. Recherche et pratiques pédagogiques en langues de spécialité Cahiers de l'Apliut, 34(1), 90-105. Retrieved from http://journals. openedition.org/apliut/5037

10. Illés, C. B., Hurta, H., \& Dunay, A. (2015). Efficiency and profitability along the lifecycle stages of small enterprises. International Journal of Management and Enterprise Development, 14(1),
56-69. https://doi.org/10.1504/ IJMED.2015.069311

11. ISO 9001:2015 - Quality Management Systems Certification (2015). Retrieved from http://www. qrocert.com/iso9001-15.aspx

12. Johnson McPhail, C. (2016). From Tall to Matrix: Redefining Organizational Structures. Change: The Magazine of Higher Learning, 48(4), 55-62. https://doi.org/10.1080 /00091383.2016.1198189

13. Jones, G. A., \& Oleksiyenko, A. (2011). The internationalization of Canadian university research: A global higher education matrix analysis of multi-level governance. Higher Education, 61(1), 41-57. Retrieved from http://citeseerx.ist. psu.edu/viewdoc/download?doi=10 .1.1.470.2293\&rep=rep 1\&type $=$ pdf

14. Jones, S., Applebee, A., Harvey, M., \& Lefoe, G. (2010). Scoping a distributed leadership matrix for higher education. In M. Devlin, J. Nagy \& A. Lichtenberg (Eds.), 33rd Higher Education Research and Development Society of Australasia. Retrieved from http://citeseerx.ist. psu.edu/viewdoc/download?doi=10 1.1.884.5993\&rep=rep1\&type=pdf

15. Kaz, E. (2017). Trust in the Development of Labor Relations and Well-being at Work. The European Proceedings of Social \& Behavioural Sciences, 19, 291297. Retrieved from http://www. futureacademy.org.uk/files/images/ upload/WELLSO2016F40.pdf 
16. Khmarskyi, V., \& Pavlov, R. (2016). Ranking system for Ukrainian banks based on financial standing. Actual Problems of Economics, 10, 348-360. Retrieved from https:// www.researchgate.net/publication/309811359_Ranking_system_ for_Ukrainian_banks_based_on_financial_standing

17. Khmarskyi, V., \& Pavlov, R. (2017). Relation between marketing expenses and bank's financial position: Ukrainian reality. Benchmarking: An International Journal, 24(4), 903-933. https://doi.org/10.1108/BIJ-022016-0026

18. Krzysztof Goś, M. A. (2015). Efficiency considerations of matrix structures in multinational corporations (Doctoral dissertation). Cracow University of Economics. Retrieved from http://www.wz.uw. edu.pl/files/aktualnosci_pliki/Summary_Krzysztof_Gos.pdf

19. Lisyutkin, M. A., \& Froumin, I. D. (2015). How Do Universities Degrade? Toward a Formulation of the Problem. Russian Education \& Society, 57(6), 442-458. https://doi.or g/10.1080/10609393.2015.1096136

20. Maxwell, T. W., \& Smyth, R. (2010). Research supervision: the research management matrix. Higher Education, 59(4), 407-422. Retrieved from https://www.researchgate.net/publication/225341478_Research_supervision_The_research_management_matrix

21. Nepal, K. P. (2012). An approach to assign individual marks from a team mark: the case of Australian grading system at universities. Assessment \& Evaluation in Higher Education, 37(5), 555-562. Retrieved from http://www.tandfonline.com/ doi/abs/10.1080/02602938.2011.5 55815

22. Pakarinen, M., \& Virtanen, P. J. (2017). Matrix organizations and cross-functional teams in the public sector: a systematic review. International Journal of Public Sector Management, 30(3), 210-226. https://doi. org/10.1108/IJPSM-04-2016-0065

23. Rodionov, O. V. (2012). Formation of innovative organizational structure in managing the quality of higher education. Project management and development of produc- tion, 1(41), 98-104 [in Ukrainian]. Retrieved from http://www.irbisnbuv.gov.ua/cgi-bin/irbis_nbuv/ cgiirbis_64.exe?I21DBN=LINK\&P2 $1 \mathrm{DBN}=\mathrm{UJRN} \& Z 21 \mathrm{ID}=\& S 21 \mathrm{REF}=$ $10 \& S 21 \mathrm{CNR}=20 \& S 21 \mathrm{STN}=1 \& S 21$ $\mathrm{FMT}=\mathrm{ASP} \_$meta\&C21COM=S\&2 S21P03 $=F I L A=\& 2$ S21STR=Uprv_2012_1_16

24. Rusinko, C. A. (2010). Integrating sustainability in management and business education: A matrix approach. Academy of Management Learning \& Education, 9(3), 507519. Retrieved from https://sustain. drupal.ku.edu/sites/sustain.ku.edu/ files/files/Rusinko_sust $\% 20$ in $\% 20$ higher\%20ed\%20matrix.pdf

25. Schnetler, R., Steyn, H., \& van Staden, P. J. (2015). Characteristics of matrix structures, and their effects on project success. South African Journal of Industrial Engineering, 26(1), 11-26. Retrieved from http:// sajie.journals.ac.za/pub/article/ view/1096/580

26. Sharata, N. (2015). To issues of the organizational management structure for innovation-pedagogical activity in universities. Collection of scientific works of Pavlo Tychyna Uman State Pedagogical University, 2, 401-413 [in Ukrainian]. Retrieved from http://library.udpu. org.ua/library_files/zbirnuk_nayk_ praz/2015/2/52.pdf

27. Standards and Guidelines for Quality Assurance in the European Higher Education Area (ESG). (2015). Brussels, Belgium. Retrieved from http://www.enqa.eu/wp-content/ uploads/2015/11/ESG_2015.pdf

28. Telizhenko, O. M., Luk'ianykhin, V. O., \& Baistriuchenko, N. O. (2016). Project-focused approach to organization of the educational process. Bulletin of the National Technological University "Kharkiv Polytechnic Institute" - Series "Strategic management, management of portfolios, programs and projects", 1(1173), 30-35 [in Ukrainian]. Retrieved from http:// repository.kpi.kharkov.ua/handle/ KhPI-Press/21627

29. The Law of Ukraine "On Higher Education": passed on 1 July 2014, № 1556-VII [in Ukrainian] (2014). Retrieved from http://zakon3.rada. gov.ua/laws/show/1556-18

30. Tvaronavičienė, M., Shishkin, A., Lukáč, P., Illiashenko, N., \& Zapototskyi, S. (2017). Sustainable economic growth and development of educational systems. Journal of International Studies, 10(3), 285-292. https://doi.org/10.14254/20718330.2017/10-3/21. Retrieved from https://jois.eu/files/20_423_Tvaronaviciene\%20et\%20al.pdf

31. Udy Jr, S. H. (1959). "Bureaucracy" and "Rationality" in Weber's Organization Theory: An Empirical Study. American Sociological Review, 24, 791-795. Retrieved from http://www.jstor. org/stable/2088566?origin=JSTORpdf\&seq=1\#page_scan_tab_contents

32. Vasylieva, N. (2013). Forecasting of prices in the field of cropsgrowing in Ukraine and regions. Economic Annals-XXI, 11-12(2), 26-29. Retrieved from https:// www.researchgate.net/publication/290934314_Forecasting_of_ prices_in_the_field_of_crops-growing_in_Ukraine_and_regions

33. Velychko, O. (2014). Fundamental basis and connection of modern entrepreneurial logistics and SCM. Review of European Studies, 6(4), 135-146. https://doi.org/10.5539/res. v6n4p135

34. Velychko, O. (2015). Integration of SCOR-modeling and logistical concept of management in the system of internal transportation of milk cooperative. Mediterranean Journal of Social Sciences, 6(1S2), 14-24. https://doi.org/10.5901/mjss.2015. v6n1s2p14

35. Velychko, O., \& Velychko, L. (2017). Logistical modelling of managerial decisions in social and marketing business systems. Journal of International Studies, 10(3), 206-219. http://dx.doi.org/10.14254/20718330.2017/10-3/15

36. Ying, F. U., Zhang, C., Zhang, Y., \& Chang, K. (2016). Management Pattern Discussion and Practice of Graduate Students Vertical Research Group Based on Matrix Organization Structure. Proceedings of the 3rd International Conference on Advanced Education and Management, Hangzhou, Zhejiang, China. Retrieved from http://dpi-proceedings.com/index.php/dtssehs/article/ view/4339/3977 